\title{
STUDY OF CONSERVATION PROCESS ADOPTED FOR MUGHAL GARDEN AND MONUMENTS IN HASAN ABDAL, PAKISTAN
}

\author{
Faiqa Khilat* \\ Muhammad Y. Awan** \\ Saima Gulzar***
}

\begin{abstract}
It is an established fact that the conservation, preservation and restoration of historic monuments and urban areas is considered to promote regional assets at international level. Through historic literature review it was found that Pakistan has many such attractions which need appropriate attention by the authorities regarding their conservation. Hasan Abdal is a historic town, in Northern Punjab, Pakistan and was once, a desired place for many Mughal emperors for their stopovers. They constructed many monumental structures such as Makbara-e-Hakeeman, Lalazar Garden and Shahjehani Sarai here. These monuments are now under the supervision of Department of Archeology and Museums, Pakistan. Some of these monuments exist and others have deteriorated with the passage of time. This paper aims to study the conservation process of Mughal Monuments situated in Hasan Abdal Town to highlight their existing condition and to save them from further decay. The international conservation practices have been studied and the selected Mughal monuments are analyzed. Surveys, interviews with official and analysis of previous conservation work enabled the study to conclude the aspects effecting the conservation of these monuments. The research is helpful for the authorities to re-evaluate the conservation practice and to implement these in a more appropriate way.
\end{abstract}

Keywords: Conservation, garden, monuments, Mughal, tomb, Hasan Abdal.

\section{INTRODUCTION}

In history built environment is considered an important element as a record which encompasses the social and economic value of a particular urban area. It highlights the methods and techniques of construction and some sociopolitical constraints of the past, since heritage promotion and its values travel from one generation to another. Without knowing the history, people cannot analyse the living and cultural norms of their ancestors. The conservation of built heritage provides the perfect representation of the roots, identity, destiny and distinctiveness of a specific period of history (Fielden, 2003). Conservation and preservation of the built environment means to keep alive the historic setting, as long as possible in its original settings for the knowledge and pride of the future generations. The built environment consists of various monuments and archaeological sites having significant importance in terms of its construction style, decorative features and its historical association (Appleyard, 1979). The architectural conservation of monuments exhibits the value and significance of the constructed ornament. It contributes to the futuristic development related to original existence. It does not replicate the past but infact it enriches the harmony of the past into new features for the future. The traditions thus prolong in the form of built examples, and give an area economic and social enhancement.

Conservation of built heritage is a key issue under consideration worldwide. Internationally, it is believed

* Faiqa Khilat, University of Management and Technology, Lahore.

Email correspondence: faiqa.khilat@umt.edu.pk

** Muhammad Y. Awan, University of Management and Technology, Lahore.

Email correspondence: yusuf.awan@umt.edu.pk

*** Dr. Saima Gulzar, Associate Professor, Department of Architecture University of Management and Technology, Lahore.

Email correspondence: saimagulzar@yahoo.com 
that different values of heritage in terms of emotion, culture and usage are enhanced by its promotion. Pakistan is a developing country and the position of conservation is similar as that of other countries which are in the state of development. Though there are legislations and acts for conservation of built form, but there is a strong need for their implementation. The listing system is required to be refreshed at innovative levels. The positive aspect is the involvement and interest of local authorities and the emergence of some voluntary organizations that are interested in safeguarding the built heritage. These societies enhance awareness among the general puplic about the signicance and promotion of built heritage (Mumtaz, 1985).

\section{RESEARCH OBJECTIVE}

The objective of this research is to inspect the aspects of conservation and the processes adopted for the Mughal monuments, understanding the worth of these significant structures. The primary objective is to highlight the monumental gardens landscape of Mughal period so that the authorities pay attention to such edifices and preserve them with their original features, without compromising their authenticity.

\section{METHODOLOGY}

Qualitative research was carried out with key informants. Qualitative in-depth interviews were conducted with concerned officials. This type of interviews gave a clear picture of the requirements and conservation issues of the specific area. Images were taken to capture views of the specific area of study. Information available on the websites was gathered and literature review was conducted through reading different books, articles, journals and professional reviews related to the research. Reports and presentations were obtained from Tehsil Municipal Authority, Hasan Abdal. Detailed study of the reports and presentations, which were prepared by professionals involved in various developmental projects, was done. The monuments were also thoroughly surveyed and analysis was done.

\section{LITERATURE REVIEW HISTORY OF CONSERVATION IN PAKISTAN}

The history of conservation of built heritage in Pakistan starts from the British times back in the early ninteenth century. At this time conservation related legislation was prepared and its implementation started when British Raj was established in the sub-continent. The British Archaeology Department, made the Indian Act in 1885. The British Government wrote letters to the state (provincial) government. In the letters, they asked them to look after the monuments. In 1888, the provincial government refused to take over the monuments because of lack of man power. The national government also could not help a lot, but they made a list of monuments (Mughal, 2017). Passing through different stages, after partition, an Antiquities Act 1975 was approved in 1976 and according to it, any heritage building which was seventy five years old, was considered as a monument that should be conserved (figure 1).

Internationally, the Gardens are defined as a separate category as found in Florence Charter on Historic Gardens 1981. This was done after UNESCO's concern on the beautification and safeguarding recommendations of cultural landscape and gardens in 1962. The recommendations encompassed landscape management, planning and protection. In Pakistan prior attention was given to the large scale gardens in Lahore like Shalimar Garden and those in the vicinity of Lahore Fort. The dilemma was that other small cities' gardens were not given any attention although they have been a significant part of Mughal history.

\section{Location of Hasan Abdal Town}

Hasan Abdal is situated in the North of Punjab, Pakistan. It is one tehsil of District Attock. It is located at a distance of forty kilometers northwest of Rawalpindi (figure 2).

\section{Mughal Emperors in Hasan Abdal, Pakistan}

Hasan Abdal Town has a long history. It was once the land of gorgeous views which was an attraction for many of the Mughal visitors, Sikh and British invaders. Mughal emperors had great interest in the natural beauty of this town and so they stayed here and constructed monumental structures (Cunningham and Alexander, 2015).

\section{Emperor Akbar}

In the reign of Emperor Akbar his allocated governor of the area was Shams al-Din Khawafi. He constructed 
PROVINCE: North West Fronticr

PROVINCE: Sindh

\begin{tabular}{|c|c|c|c|}
\hline kEX & DISTRIST & 는 & $\underline{\mathbf{s}}$ \\
\hline 1. & Mensehres & 2 & 2 \\
\hline 2. & Abbocabed & 4 & 26 \\
\hline 3. & Mardan & 0 & 26 \\
\hline 4. & Peehawar & 3 & 9 \\
\hline s. & Decs Inma11 & & \\
\hline & Khan & 3 & 2 \\
\hline 6. & aannu & $z$ & 2 \\
\hline
\end{tabular}

PROVINCE: Puniab

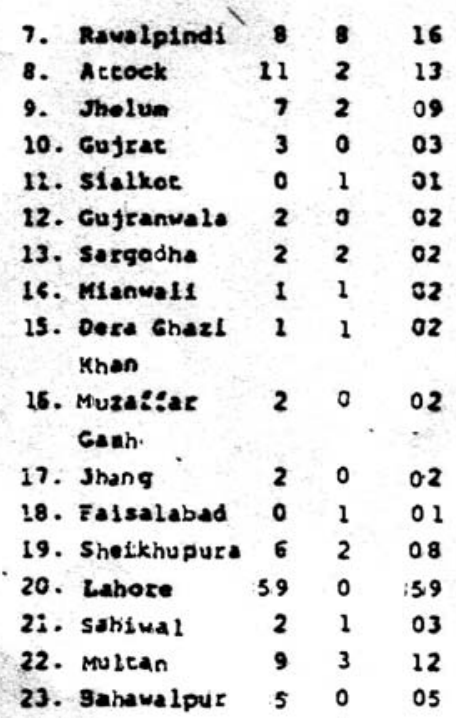

TOTAL $\quad \begin{array}{lll}120 & 24 & 144\end{array}$

\section{PRCVINCE: Baluchistan}

$\begin{array}{lrrr}\text { 21. Loralal } & 0 & 3 & 03 \\ \text { 25. Oudcta } & 0 & 10 & 10 \\ \text { 26. Sibi } & 1 & 0 & 01 \\ \text { 27. Kalat } & 0 & 1 & 01 \\ \text { 28. Kharan. } & 5 & 1 & 06 \\ \text { 29. Nasirabad } & 0 & 1 & 01 \\ \text { 30. Lasbela } & 2 & 2 & 04 \\ \text { Total } & 8 & 18 & 26\end{array}$

$\begin{array}{lrrr}\text { 31. Sukkdr } & 3 & 1 & 04 \\ \text { 32. Nawab stiah } & 3 & 1 & 04 \\ \text { 33. Khelrpur } & 1 & 2 & 03 \\ \text { 34: Larkana } & 2 & 5 & 07 \\ \text { 35. Dadu } & 4 & 12 & 16 \\ \text { 36. Sanghar } & 0 & 3 & 03 \\ \text { 31. Hyderabad } & 16 & 0 & 16 \\ \text { 38. Tharparkar } & 26 & 2 & 28 \\ \text { 39. Jadln } & 0 & 1 & 01 \\ \text { 10. That } & 31 & 5 & 36 \\ \text { 11. Karach1 } & 4 & 2 & 06\end{array}$

$\begin{array}{llll} & & & \\ \text { totat } & 90 & 34 & 124\end{array}$

GRANO TOTAL $232123 \quad 355$

M- Monument S-site T- Recal

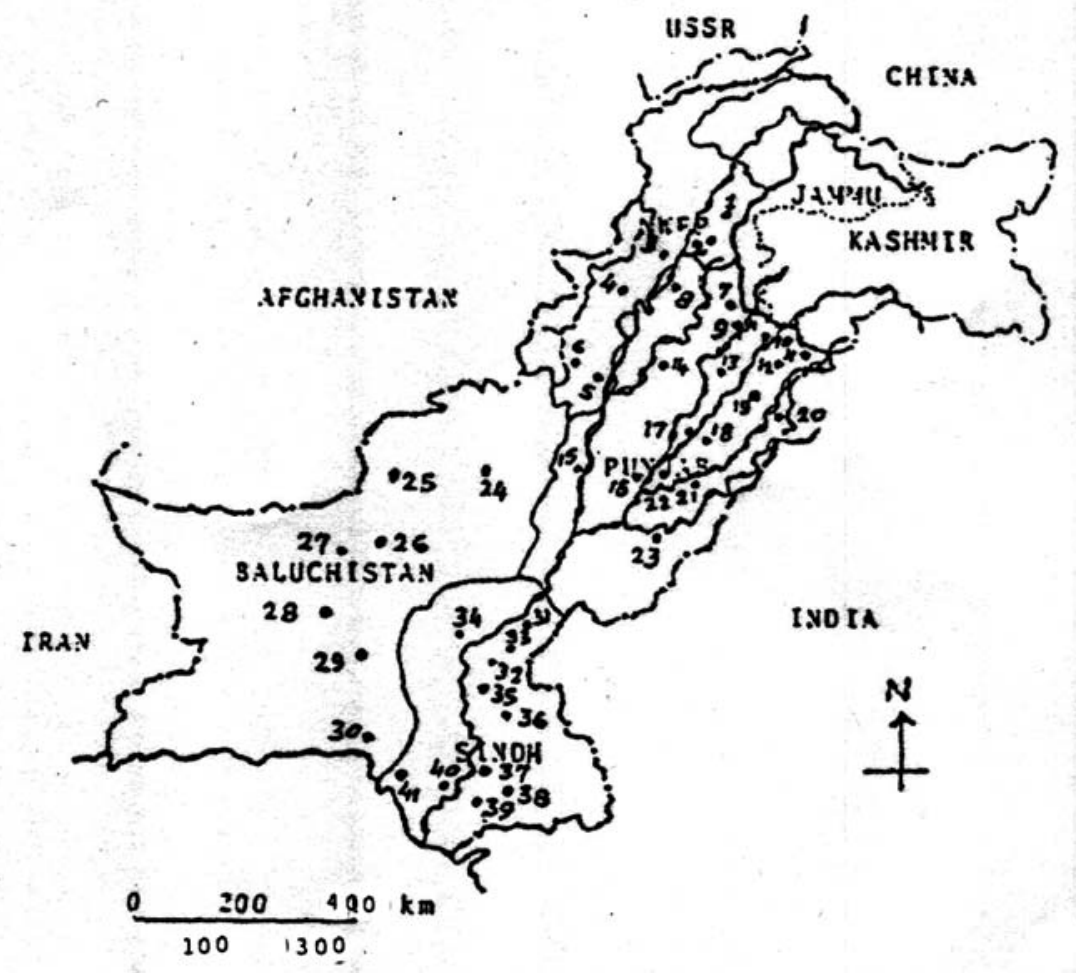

Figure 1: Listed monuments by Department of Archaeology and Museums, Pakistan Source: Department of Archaeology, Pakistan 


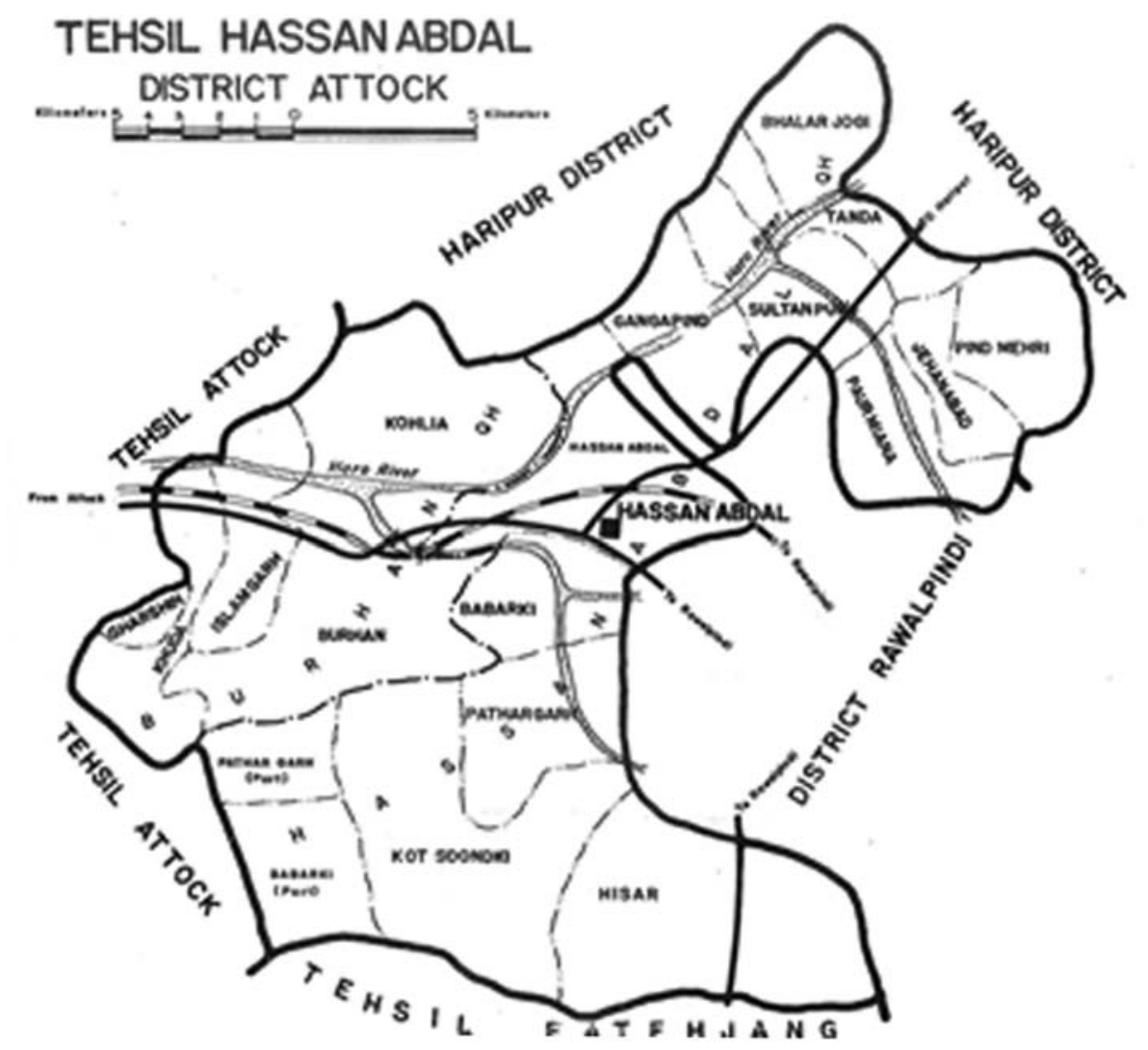

Figure 2: Location of Hasan Abdal, Pakistan

a vault for himself to be his tomb, known as Makbara Hakeeman. Akbar also stayed in the town while coming back from Kashmir. He visited this town almost seven times in the years 1581, 1585, 1586, 1589, 1590 and 1592 (Jarret, A., et.al., 1907).

\section{Emperor Jahangir}

Hasan Abdal was visited by many famous people in history, mostly by Mughal and Sikh Emperors. Emperor Jehangir spent three days in this city, and cited Hasan Abdal as a very beautiful place with sweet river water and gorgeous mountains (Rampuri, 2012). He stayed at least six times here during his lifetime. In his own words, he felt glad to do fishing here and have put golden pins in the fish's nose.

\section{Emperor Shah Jahan}

Emperor Shah Jahan visited Hasan Abdal five times on his journeys back to Kashmir and he always preferred to stay here. He constructed the famous Lala Rukh Garden and Shahjahani Sarai (Lahori, 1875).

\section{Emperor Aurangzeb Alamgir}

Emperor Aurangzeb stayed here from 2nd July 1647 $-2^{\text {nd }}$ January 1676 which is the most time spent by any other Mughal emperor in Hasan Abdal (Saddique, 1977). Hasan Abdal gained administrative importance in his region. He spent his two Ramadan and Eid here (Kahn and Nath, 1947).

\section{Mughal Prince and Princess}

Dara Shikho's sister, Jahan Ara Begam visited and stayed here many times and enjoyed her stay here, which is reflected in her poetry. She praises the gorgeous and pleasant environment in poetic words (Saddique, 1977).

\section{ANALYSIS AND DISCUSSIONS}

The Mughal period constructions are found in a compound or an enclosure in Hasan Abdal consisting of the: 


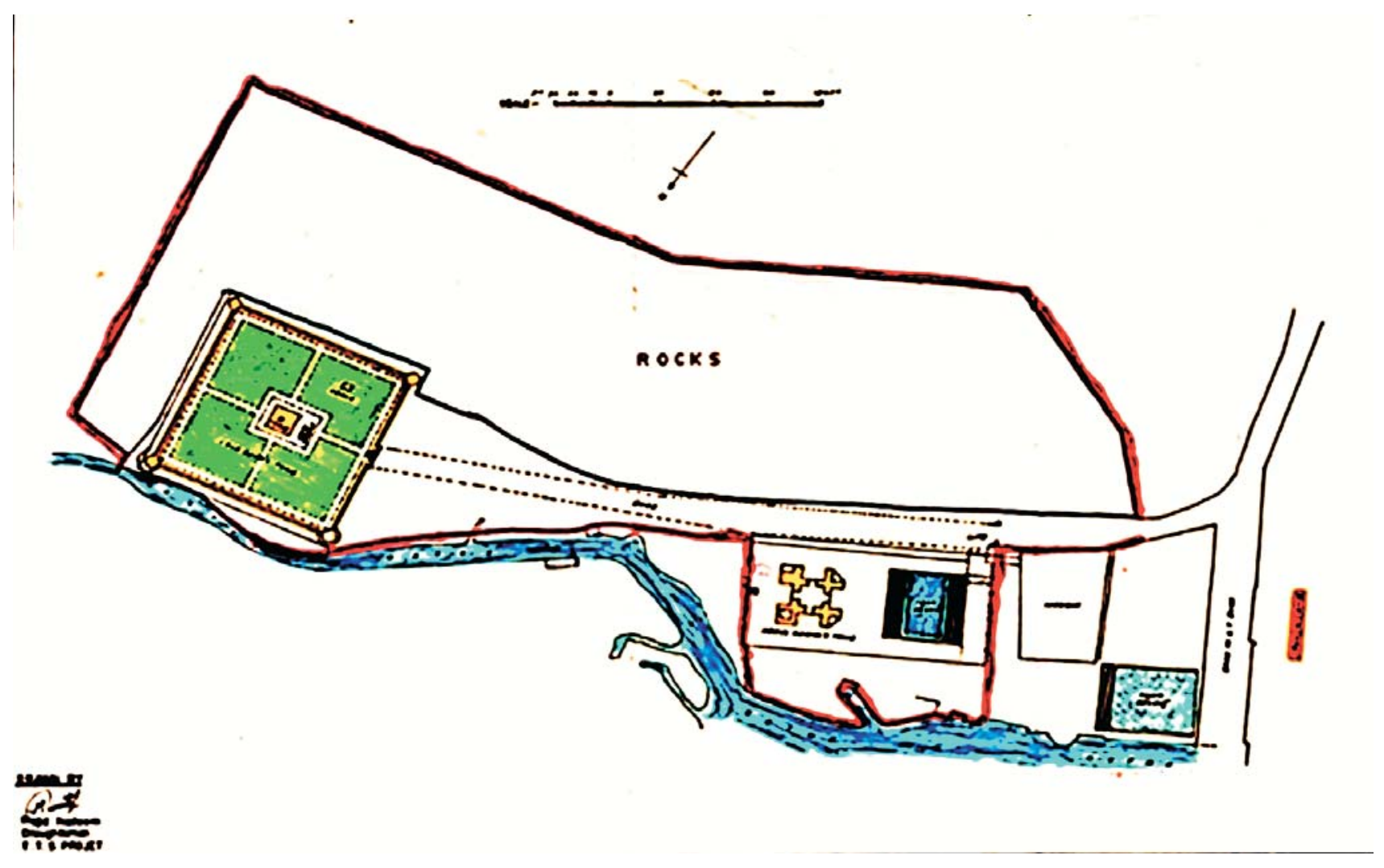

Figure 3: Map of enclosure of Mughal period construction.

- Tomb and Garden of Lala Rukh

- Maqbara Hakeeman and the fish pond.

These monuments are listed monuments under the Directorate General of Archeology, Government of Punjab, Pakistan (GoP Religious Monuments, 2017). Figure 3 shows the map of the enclosure located at the center of Hasan Abdal Town, Pakistan.

At the entrance of Lala Rukh Garden, there is an enclosure containing a fish pond. There is a monumental Mughal tomb on the left hand side and lush green mountain on the right. Just at the front there is a gateway of Mughal Garden of Lala Rukh. This Garden has a centrally raised platform having a grave on its top. The details of these structures are described here.

\section{A. Tomb and Garden of Lala Rukh}

This garden is a typical Caharbagh design, i.e. a famous Mughal construction style of gardens. It is surrounded by a brick wall finished with traces of lime plaster.
With the condition of the wall it seems that it has been changed and repaired with cement plaster many times (Siddique, 1977). The garden was originally constructed at the bank of a fresh natural water stream (figure 4). The garden is now surrounded by various added constructions.

Moreover, figure 5, shows that this garden inspired the painter to paint its gorgeous surroundings also.

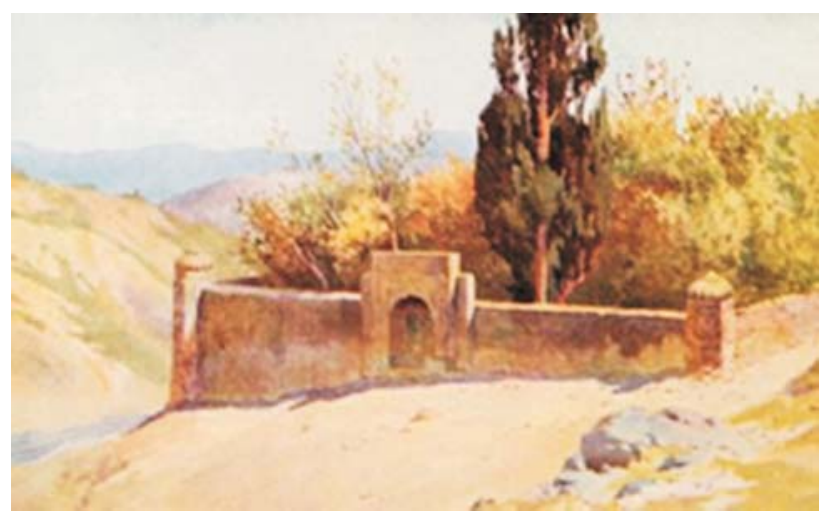

Figure 4: Painting of Lala Rukh Garden in 1924 (Siddique, 1977). 

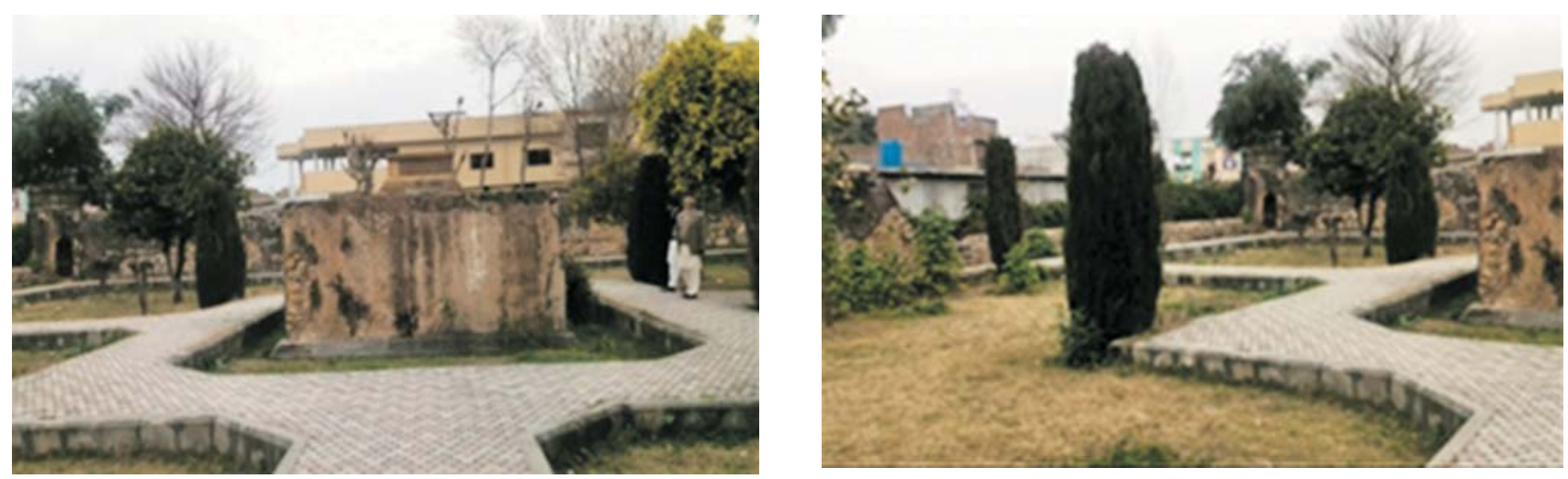

Figure 5a,b: Views of Chaharbagh of Mughal Garden known as "Lala Rukh Garden".

There were open backgrounds, beautiful vistas which attracted the Mughal emperors for the construction of this garden.

The grave within the Garden is associated to a Mughal princess Lala Rukh who got sick and died while passing from this area. Some people associate this grave with Noor Jahan. This however has not been proven because Emperor Jahangir does not mention this tomb in his memorial. In 1905, in revenue records it is mentioned as Maqbara Bibi LalaRukh (Tomb of Lala Rukh). It is said that she was the daughter of Emperor Aurangzeb Alamgir and was fortunate lady of British officer Thomas Moore. The early 19th century English travelers, like Elfinstone and William MoorCraft and even Alexander Cunningham visiting the area in 1888 AD do not call it Lala Rukh's Tomb. The tomb is mentioned in the publication of Thomas Moor's Lala Rukh, published from London in 1846 AD (Siddique, 1977). Hence, who is in this grave is unknown. This Garden is also mentioned as the Tomb of Cypress trees or "Saroo Wala Maqbara". The garden has Cypress trees as its identity of a Mughal garden like Shalimar Garden and others (Hussain, 2015).

The cenotaph is in sandstone and stands on a high platform at the middle of a large enclosure, which is approached through a door on the west. This raised platform has a width of twelve feet eleven inches by fifteen feet and height of eight feet. A spring flows at the north of the enclosure wall. To save this area from being washed away a small wall was built at the north side in the past. The part of the wall was constructed with one thousand eighteen cubit feet of coursed rubble stone masonry cement mortar laid over one hundred fifty two cubic feet six inches thick layer of cement concrete in 1952-53 (Siddique, 1977).

The tomb fascinates a number of tourists for its picturesque beauty and dreamy associations. The Sikhs visiting Hasan Abdal on their pilgrimage frequently visit this place. There is another unknown grave at one corner of this chaharbagh of Lala Rukh Tomb.

\section{Conservation process}

The Department of Archeology has a pipeline project for the conservation of this garden. The initial survey was done in the year 2006 (Hussain, 2015). According to the Head of the Department of Archaeology, the project was taken as a part of their ongoing conservation project, i.e. Master Plan for Development and Restoration of Archaeological Sites from Taxila to Swat (Taxila Section) (Government of Pakistan, 2012). Figure 6 shows the survey being done by the Department of Archaeology.

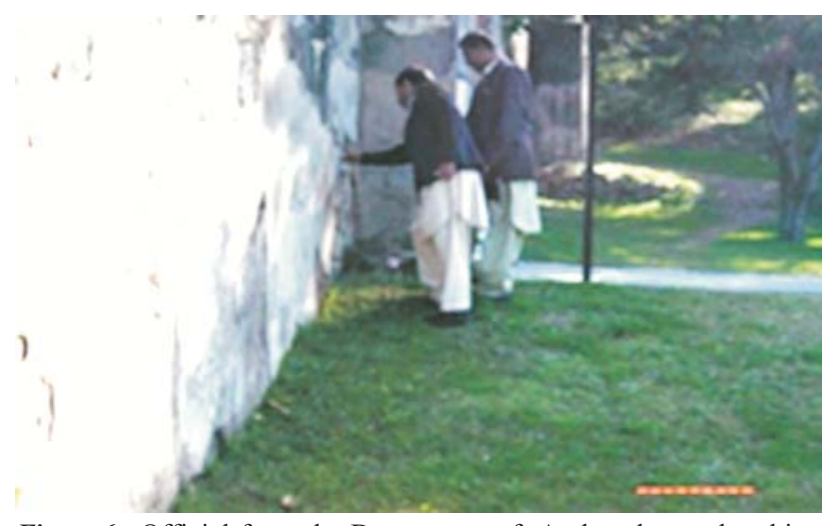

Figure 6: Official from the Department of Archaeolgy undertaking survey (pictures taken in 2006). 


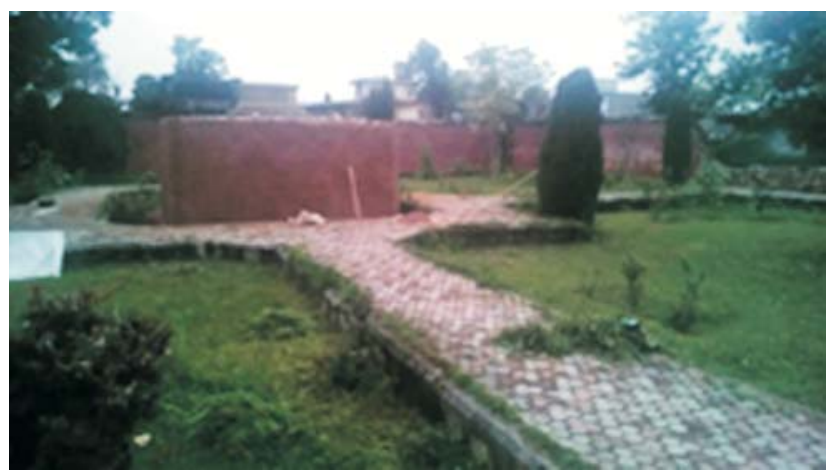

Figure 7: Views of Lala Rukh Garden under Conservation Process in November 2016.

In November 2016, Lala Rukh Garden conservation process was completed (figure 7). In the process, the plaster on the walls was repaired but surkhi was mixed in it. The officials of the Department of Archeology and Museum claim that the original plaster done on the wall was lime plaster with traces of surkhi in it. Surkhi is a powder of red bricks which gives red color to plaster (Gohar, 2015).

\section{Makbara Hakeeman (Hakim's Tomb)}

Makbara-e-Hakeeman or Hakim's Tomb lies just at the entrance of the Mughal monuments enclosure at the west side of Lala Rukh Garden. It is located just opposite the Gurdwara (Sikh's place of worship). The tomb and the fish pond are situated on an extensive platform measuring one hundred twenty-six feet long and sixty eight feet wide. This Tomb was constructed by Khawaja Shams uddin Khawafi who was the Governor of Punjab in 1589 AD. The construction of the Tomb was completed in almost two years. This tomb is constructed with a similar material as used in Attock Fort and the construction period is also the same. Khawaja Shams uddin Khawafi constructed this tomb for himself, but Emperor Akbar had two very reputable ministers, Hakim Abdul Fateh Gilani and Hakim Hamam buried here. When hakims died in 1599 , Emperor Akbar ordered to bury them in this tomb overlooking the wish of Khawaja Shams uddin Khawafi (Jarret, et.al., 1907). During the Sikh rule (1799-1849), the graves of respected hakims were leveled and this tomb was used as Munshi Khana (clerk office) (figures $8 \& 9)$.

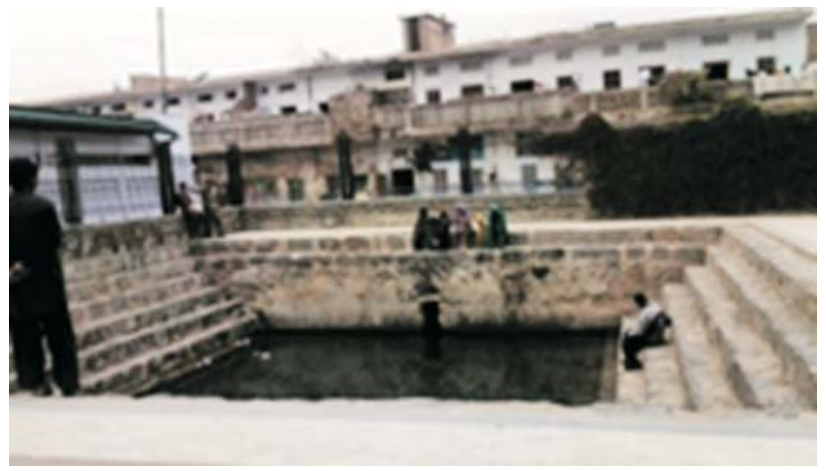

Figure 8: View of fish pond.

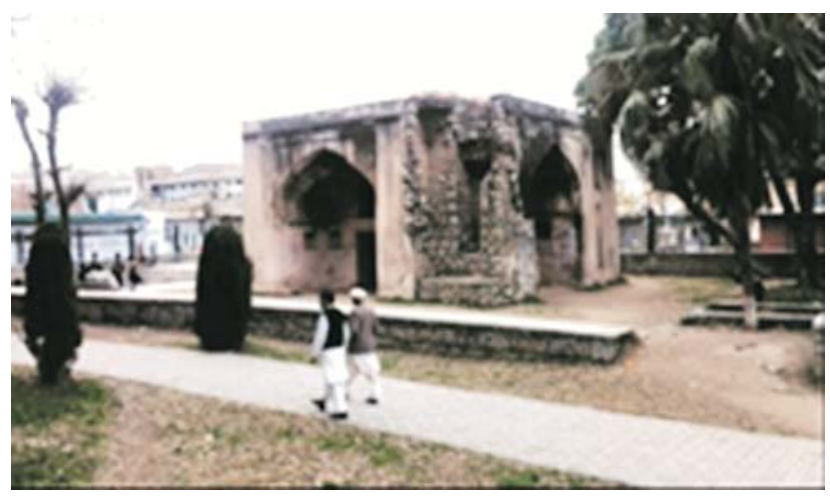

Figure 9: View of the Tomb of Hakim.

\section{Conservation process in $2005-2006$}

The Tomb was conserved in 2013 by the Department of Archeology. The facade of the Tomb was re-plastered with lime plaster and the roof and its access steps were cleared by removing plants from the structure (Hussain, 2015).

Labourers from Chiniot, Lahore and Multan were hired by the Department of Archaeology and they worked on the Tomb of Hakeeman. Pucca Qali plaster was done with ingredients such as lime, sand, surkhi and jute. There were no traces of fresco painting found on the walls so plaster finish was taken as the final finish (Gohar, 2015) (figures $10-12$ ). 


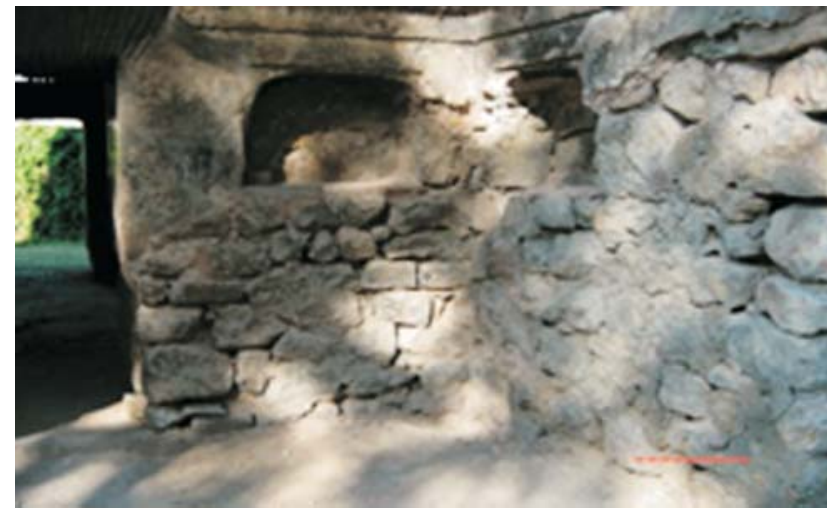

Figure 10: Interior views before conservation works.

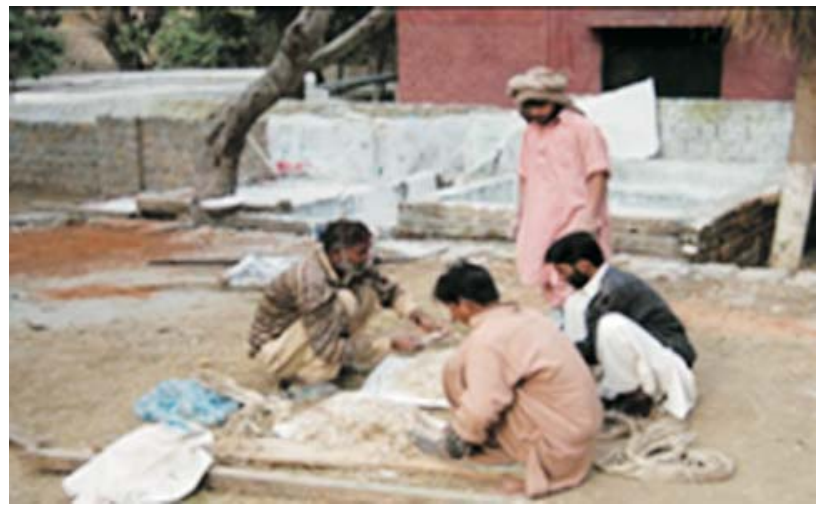

Figure 11: Preparation of Mughal lime plaster on site with traditional methods.
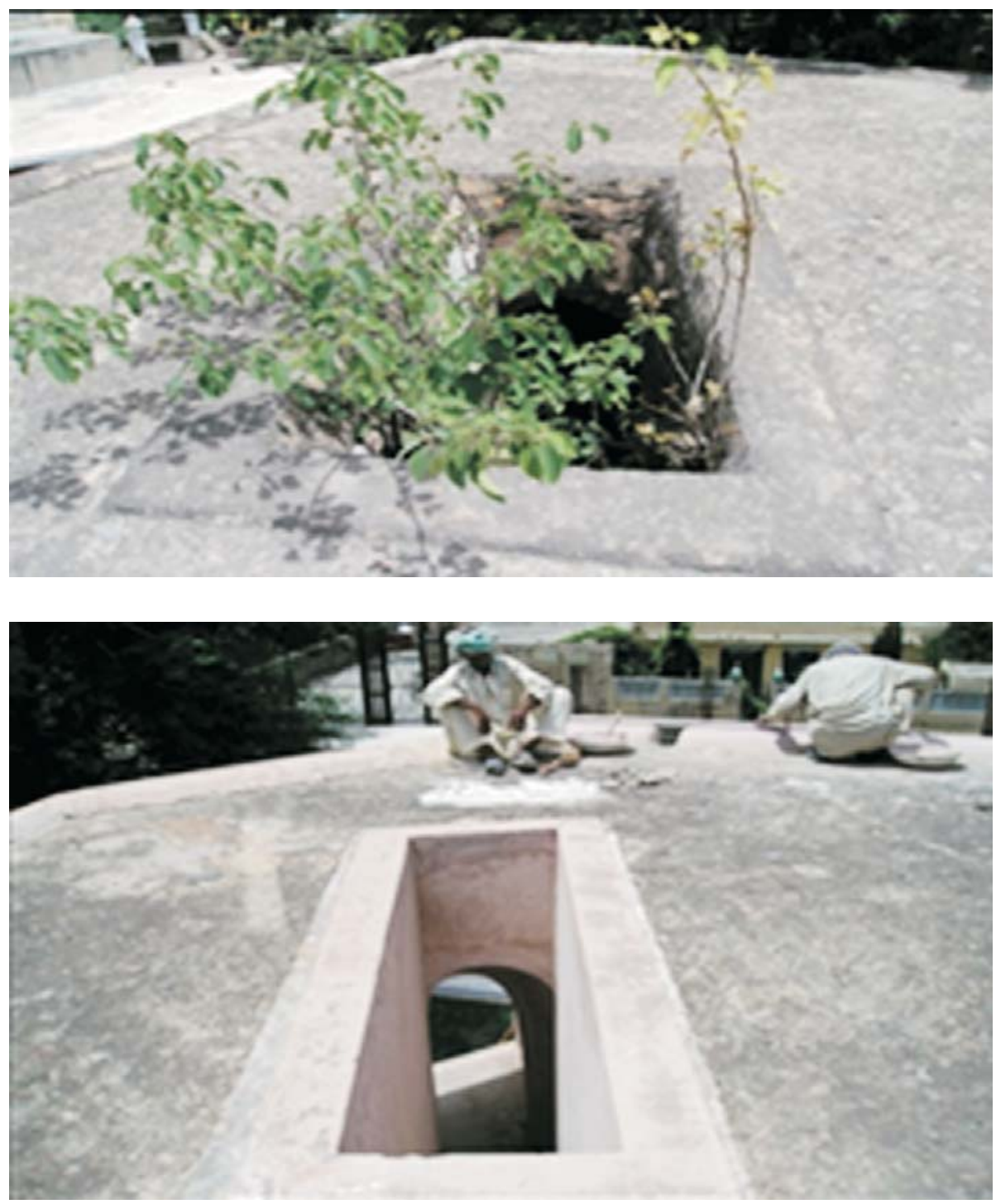

Figure 12a,b: Roof top of the tomb before and after renovation (Government of Punjab, 2012). 
The fish pond is adjacent to the Tomb Hakiman having its own character. This pond is a fresh water pond through which the nearby water steam passes. It contains Mahasheer fish. There is a famous myth about these fish that they have golden pins in their noses and they are sacred because if they are caught the meat becomes blood. Emperor Aurangzeb Alamgir has also described this pond in his writings and it is quoted that he put golden pins in the noses of some fish (Rampuri, 2012) (figure 13).

\section{Landscaping of the pathway and park}

In 1997, the pathway between Tomb of Hakiman and Lala Rukh Garden was paved with tiles on the orders of a local Member of Parliament. In this conservation process the sides and walls of the pathway were left untouched. In the process of conservation in 20052006, the Tomb of Hakiman and its premises till Lala Rukh Garden were maintained to some extent. Some landscape elements such as benches and rose plants

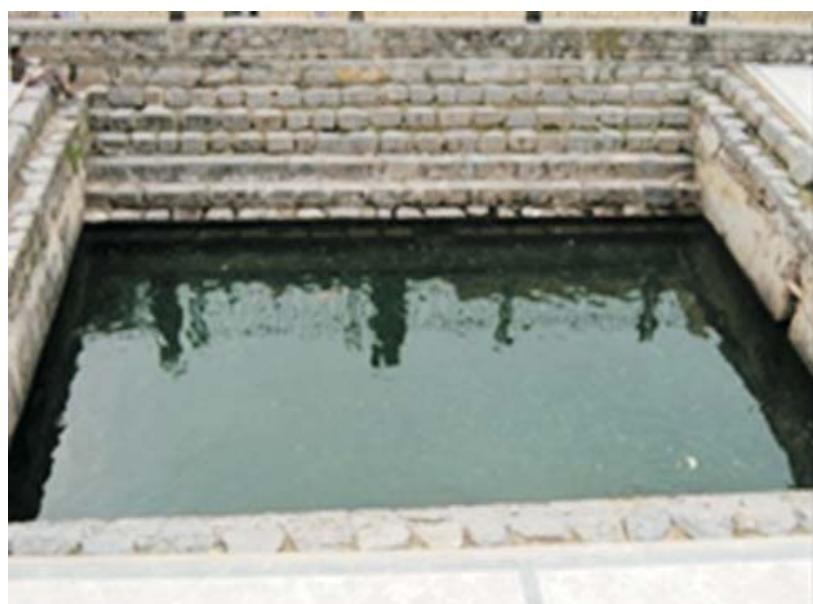

Figure 13: Fish pond containing Mahasheer fish.

were added (figure 14). Access plantation, shrubs and vines were removed and paths were cleared for the visitors and tourists to relish the Mughal monuments.
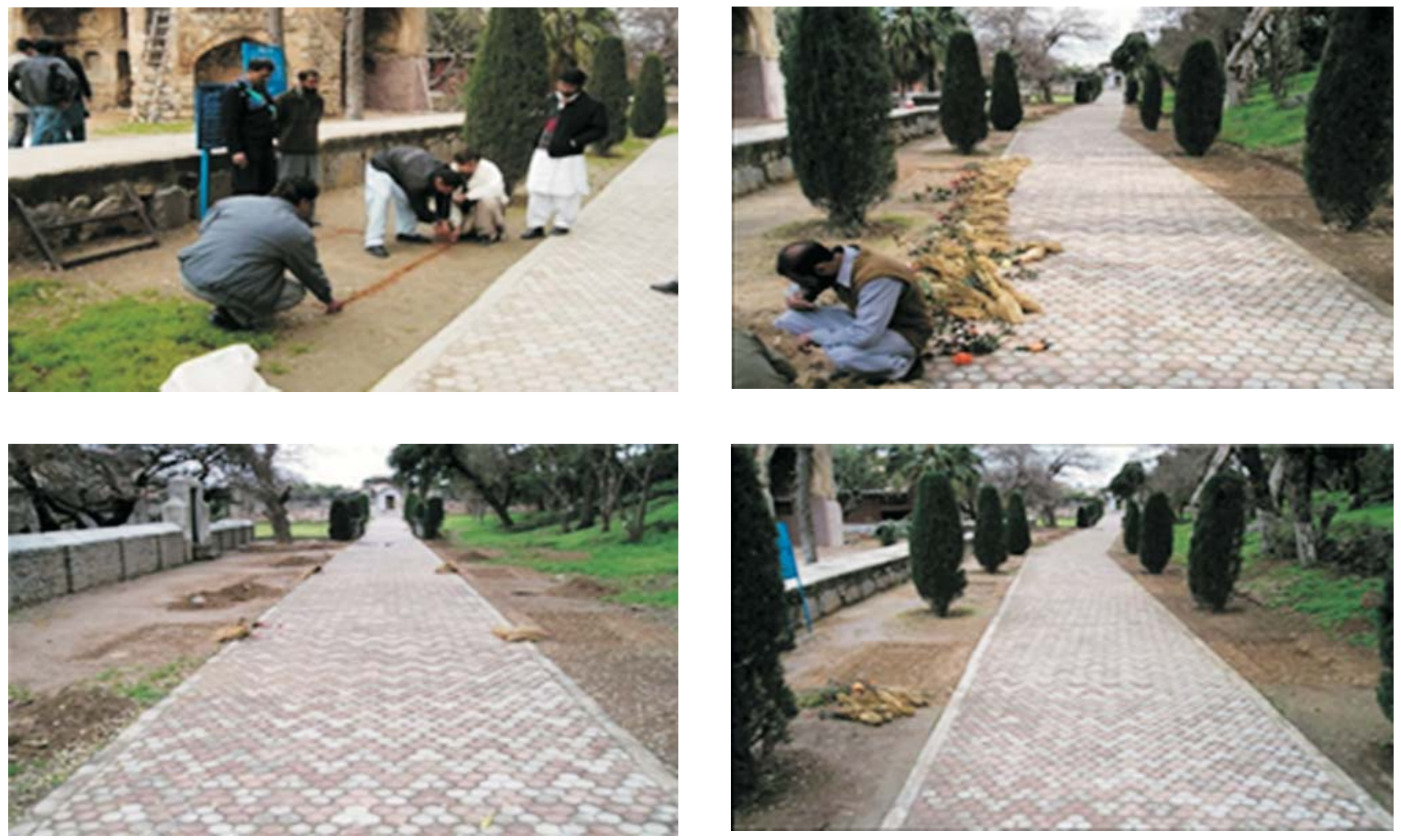

Figure 14a,b,c\&d: Rose plants been embadded along the path leading from Hakeem's Tomb to Lala Rukh Garden (Government of Pakistan, 2012). 
Moreover local crafted concrete benches were erected in the garden to facilitate the visitors.

\section{Shahjehani Sarai}

A Sarai complex has almost vanished from its original location. This was constructed in the reign of Emperor Shahjehan on a contoured area which was leveled out. The surrounding wall was fifteen feet high from inside and varied from fifteen feet to twenty five feet from outside. It had a width of thirty one and half inch and length of five hundred thirty eight feet. It was a total square site. There were double story tower rooms at each corner in round shape having diameter of twelve feet. They were domed structures on the inside but these structures were flat roofed from top. On all sides there were ten feet square rooms with eight feet three inches veranda on the front. All construction was in brick. The roof of the rooms and verandas were in round shape and the entrance door was at the centre of the complex. The main entrance consisted of a huge door constructed with bricks, brick ballast, lime plasters and jute. Its wall was of a height of two feet seven and half inches. The mosque inside this Sarai was later added. During the Sikh reign this complex was occupied by Sikhs and Muslims were thrown out (Saddique, 1977). Now this space is over populated and crowded with small residences and is known as Mohallah Androon (Inner neighbourhood) (figure 15).

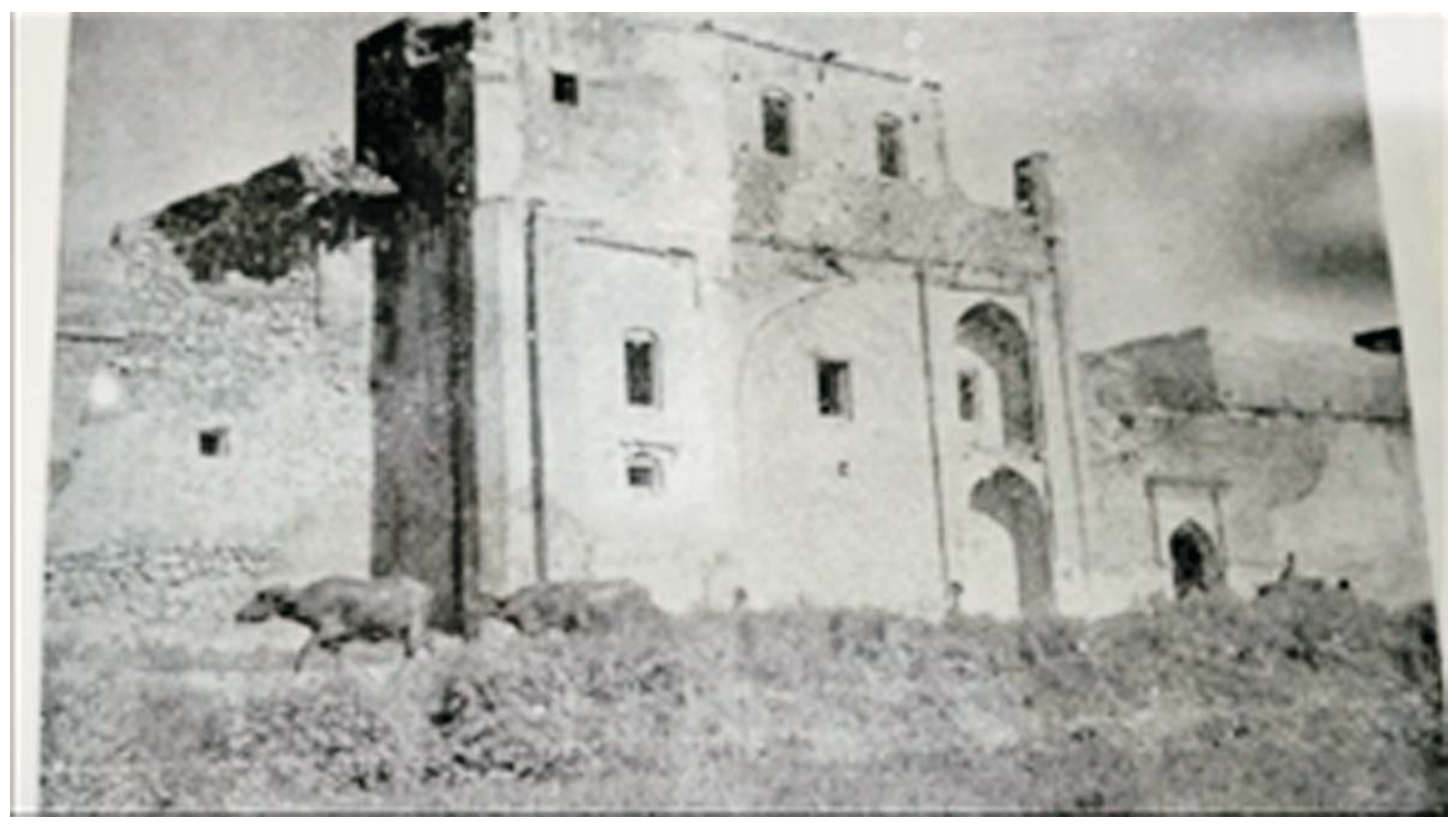

Figure 15: View of main gate of Shahjehani Sarai vanished from the scene due to illegal occupation (Siddique, 1977). 
Because of the illegal occupation and encroachments of the bazaar, the Sarai has vanished and some ruins can be seen (figure 16). Now it seems impossible to conserve this Sarai back to its original shape, as once it was a significant edifice.

\section{CONCLUSION}

The study and research on the selected Mughal monuments concludes that the conservation processes have been applied on them, but somehow the authenticity of the monuments has been affected with the passage of time. The international charters and policies have available guidelines which instruct the authorities not to compromise the authenticity of monuments but these policies were not applied in the case of Hasan Abdal. This happened because the original ingredients of the Mughal plaster have been replaced by some locally available substitutes. Furthermore, schematic surveys with latest instruments, such as laser scanners should have been used while conducting the surveys of such monuments. The major
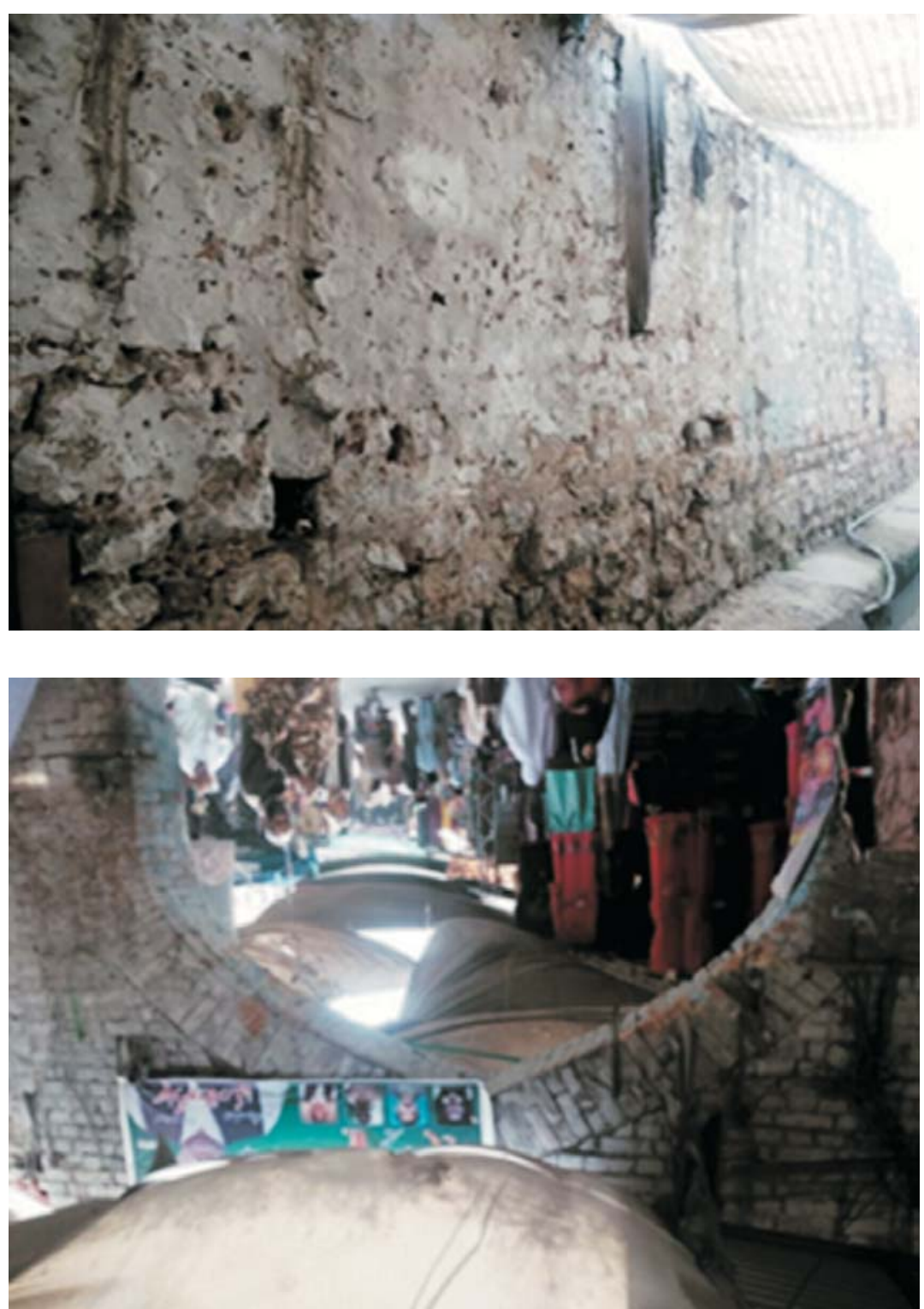

Figure 16a,b: Existing condition of main entrance gate of Shahjehani Sarai. 
issue in the conservation of these monuments seems to be the lack of funds, lack of study of historic literature, lack of realization of the significance of heritage conservation and fragile coordination of the structures.
Hence the significance of the conservation issues should be understood by the authorities and the visitors to safeguard these monuments in much deliberate way.

\section{REFERENCES}

Appleyard, D., 1979, The Conservertion of European Cities, Cambridge, Massachuessets, MIT Press.

Cunningham and Alexander, 2015, Archaeological Survey of India, Vol. 1, Classic Reprint, Forgotten Books.

Feilden, B. M., 2003, Conservation of Historic Buildings, Third edition, London, Routledge.

Government of Pakistan, 2012, "Report, Master Plan for Development \& Restoration of Archaeological Sites from Taxila to Swat (Taxila Section), Youth Affairs, Sports, Archaeology \& Tourism Department”, Directorate General of Archaeology, Government of Punjab.

Gohar, A., Interviewe, Conservator, DOAM, Taxila Museum, 18 August 2015.

Government of Punjab (GoP), Religious Monuments - Directorate General of Archaeology, 2017, "Dgarch.gop.pk", Viewed 23-05-2017, from http://www.dgarch.gop.pk/religious-monuments.

Jarrett, A. F. Allami, H. Blochmann, C. H. S., 1907, Ain-e-Akbari, Calcutta, Asiatic Society of Bengal.

Khan, S. M., and Nath, S. S. J., 1947, Maasir- i-Almagiri A History of Emperor Aurangzib Alamgir (reign1658-1707), Calkata, P.C. Ray Sri Ganga Press.

Lahori, A. H., 1875, Badshanama of Abdul Hamid Lahori, Lahore, Hafiz Press, pp. 502-503.

Mumtaz, K. K., 1985, Architecture in Pakistan, Singapore, Concept Media.

Hussain, M.S.A., Interviewee, Depty Director, DOAM, Taxila Museum, 19 August 2015.

Mughal, M.R., 2017, Viewed 04-04-2017, from http:/www.rafiquemughal.com/MUGHAL_2010_Chapter-on-HeritagePreser-In-Pakistan.pdf.

Rampuri, M. S. A., 2012, Tuzk-e-Jhangiri, Lahore: Sang-e-Meel Publication.

Siddique, M. U. H., 1977, Tareek-e-Hasan Abdal, Lahore, Matbae e Aalia. 